\title{
MEFV Mutation Frequency in Pediatric Patients with Familial Mediterranean Fever and its Relationship with Clinical Phenotypes in Marmara Region of Turkey
}

\author{
Veysel Gok, ${ }^{1}$ Ozgül Yigit, ${ }^{1}$ Ozlem Bostan Gayret, ${ }^{1}$ and Sahin Hamilcikan ${ }^{1,}$ \\ ${ }^{1}$ Bagcilar Training and Research Hospital, Department of Pediatrics, Istanbul, Turkey \\ "Corresponding author: Dr. Sahin Hamilcikan, Bagcilar Training and Research Hospital, Istanbul, Turkey. Tel: +90-5325123606, E-mail: hinsahin@gmail.com
}

Received 2017 January 24; Revised 2017 April 07; Accepted 2017 May 26.

\begin{abstract}
Background: Familial Mediterranean fever (FMF) is an autosomal recessive disorder characterised by recurrent fever, peritonitis, pleuritis, and arthritis. Three hundred and seventeen mutations and polymorphisms related to FMF have been identified to date. Objectives: The evaluation of the distribution of genetic mutations in children whose FMF study was conducted in Marmara region in Turkey and the relationship between clinical findings and the mutation was aimed in the study.

Methods: The files of all patients whose pre-diagnosis of FMF and MEFV gene mutation analysis were made, were evaluated retrospectively. The results of the MEFV gene mutation analysis of the patients were screened retrospectively. Common MEFV gene mutation analyses were studied. The age, gender, presenting complaints, and histories of the patients were obtained from the files and records.

Results: A total of 150 patients were included in the study. The mean age of the cases was $9.37 \pm 4.43$ years; 78 were female and 72 were male. Sixty-seven (44.7\%) of the cases had abdominal pain, $30(20 \%)$ had arthralgia, 25 (16.7\%) had fever, 2 (1.3\%) had chest pain, and $30(20 \%)$ had other complaints. While the mutation with the highest frequency was $\mathrm{R} 202 \mathrm{Q}(37.2 \%)$, it was observed that allele frequencies following this were E148Q (23.4\%), M694V (21.9\%), V726A (5.1\%), and M680I (2.9\%). Abdominal pain was detected as the most frequent presenting complaint.

Conclusions: Although M694V gene mutation is the most frequently observed mutation in Turkey, we identified that the most frequent gene mutations were R202Q and E148Q in this study. This situation may be because most of our patients were from Anatolian regions where there are many ethnic groups. When the distribution of genotypes was examined by complaint, the most frequent complaint identified in all gene mutations was abdominal pain.
\end{abstract}

Keywords: Familial Mediterranean Fever, MEFV, Abdominal Pain, Fever

\section{Background}

Familial Mediterranean fever (FMF) is an autosomal recessive disorder characterised by recurrent fever, peritonitis, pleuresy, and arthritis, which occur as a result of the inflammation of serous membranes (1). The most severe complication of the disease is amyloidosis and renal failure that occur as the patient ages (2). The clinical process can be controlled with early diagnosis of the disease. However, it is not easy to diagnose FMF disease since there are no significant clinical symptoms (3). The disease is prevalent among non-Ashkenazi Jews, Arabs, Armenians, Turks, and other societies of the Mediterranean origin, as well as non-Jewish Caucasians, Indians, and Chinese $(4,5)$. Three hundred and seventeen mutations and polymorphisms have been determined so far with regard to FM (6). The FMF distribution ratio in Anatolia is approximately $1 / 400$. The most widespread mutations among Turks are M694V, M680I, V726A, R761H, and E148Q (7). The disease symptoms mostly emerge before the age of 20 , and the period of attack varies between 12 and 72 hours. There are no symptoms between the attacks, but inflammation may continue (8). The gene that causes familial Mediterranean fever was first defined in 1997. International and French FMF organizations have reported that the gene that codes the pyrin/marenostrin protein in the 16 th chromosome is related to FMF. The gene that causes familial Mediterranean fever was defined as the Mediterranean Fever (MEFV) gene. Organizations have reported that M694V, M694I, M680I, and V726A mutations exist in $85 \%$ of the patients $(9,10)$. Studies on the FMF mutation type and carrier frequency carried out in different regions of Turkey have shown that mutation frequencies differ. In this study, we aimed to assess the distribution and frequency of genetic mutations and the relationship between clinical findings and mutation in patients in the $1-17$ years age group whose genetic analysis and the pre-diagnosis of FMF were performed in the Marmara region of Turkey. 


\section{Methods}

\subsection{Study Population}

This retrospective single-centre study was carried out in a training and research hospital for child health and diseases clinic in Istanbul. Of those whose data could be retrieved, 150 patients, among 253 patients who applied to the child health clinic between August 2013 and August 2015 and whose MEFV gene mutation analysis was carried out were included in the study. The MEFV gene mutation analysis results of the patients were scanned retrospectively. In mutation analyses using multiplex polymerase chain reaction (PCR), it was observed that exon $2 \mathrm{v} 10$ of the MEFV gene was amplified. The mutations were termed heterozygous, homozygous, and compound and complex heterozygous. Heterozygous patients were confirmed by sequence analysis. Exons 2, 3, 5 and 10 were sequenced by using GML SeqFinder Sequencing System MEFV kit with Sanger sequence technology.

The patients' age, gender, presenting complaint, age of the complaint onset, the age at which the disease was diagnosed, whether they received treatment, complaints of mother, father and sibling, kinship level of the mother and father, and the hometown of the parents were taken from the files and recorded in the forms. The Tel-Hashomer criteria were used in the diagnosis of FMF. A definite diagnosis can be made in the presence of two major criteria or one major together with two minor criteria, while a possible diagnosis can be made in the presence of one major and one minor criterion (11).

\subsection{Statistical Analyses}

The NCSS (number cruncher statistical system) 2007 (Kaysville, Utah, USA) software was used for the statistical analyses. When assessing the study data, the conformity of qualitative data to normal distribution in addition to descriptive statistical methods (mean, standard deviation, frequency, percentage, minimum, maximum) were tested using student t-test. Statistical significance was accepted as $\mathrm{P}<0.05$.

\section{Results}

The age range of the cases was 1 - 17, with an average of $9.37 \pm 4.43$ years; the average age of the complaint onset was $8.77 \pm 4.20$ years. Of the cases, $52 \%(n=78)$ was female and $48 \%(n=72)$ male. The demographic characteristics of our patients are summarised in Table 1 . The distribution of homozygous, heterozygous genes, and the allele frequency of patients are shown in Table 2, and the descriptive properties according to genetic mutation of patients are summarized Table 3.
Table 1. Demographic Characteristics of the Patients

\begin{tabular}{|lcc}
\hline Variables & Min-Max & Mean \pm SD \\
\hline Age, $\mathbf{y}$ & $1-17$ & $9.37 \pm 4.43$ \\
\hline Age at complaint onset, $\mathbf{y}$ & $1-17$ & $8.77 \pm 4.20$ \\
\hline Gender & No. & $\%$ \\
\hline Female & & \\
\hline Male & 78 & 52.0 \\
\hline Consanguinity & 72 & 48.0 \\
\hline Patient complaints & 35 & 23.3 \\
\hline Abdominal pain & & \\
\hline Arthralgia & 67 & 44.7 \\
\hline Fever & 30 & 20.0 \\
\hline Chest pain & 25 & 16.7 \\
\hline Other & 2 & 1.3 \\
\hline Those who received treatment & 30 & 20.0 \\
\hline Mutation (+) & 19 & 12.7 \\
\hline
\end{tabular}

Upon examining the genotype distributions, the wild type can be observed in $40 \%$, heterozygous type in $36.7 \%$, homozygous in $5.3 \%$, compound heterozygous in $12.7 \%$, and complex heterozygous in $5.3 \%$. The rate of the disease among 150 people was $23.3 \%$, while the carrier rate was 36.7\% (Table 4).

Upon examining the distribution of the genotypes by complaints, abdominal pain was observed in $48.1 \%$ of the patients with the M694V genotype, arthralgia in $18.5 \%$, and fever in $18.5 \%$. Abdominal pain was observed in $41.9 \%$ of those with E148Q genotype, arthralgia in $25.8 \%$, and fever in $19.4 \%$. Abdominal pain was observed in $44.4 \%$ of those with R202Q genotype, arthralgia in $22.2 \%$, and fever in $13.3 \%$. Abdominal pain was observed in $57.1 \%$ of those with V726 genotype, and fever in $14.3 \%$ (Table 5).

\section{Discussion}

Familial Mediterranean fever is an autosomal recessive inflammatory disease prevalent among the Turks, Armenians, Jews, and Arabs (12). While FMF is observed at a rate of $1 / 1000$ in Turkey, the carrier rate is $1 / 5(12,13)$. FMF is a childhood disease that generally shows its symptoms between the ages of 5 and 15 years (14). Majeed et al. (15) reported that FMF starts before the age of 10 in approximately $80 \%$ of the patients, while Gedalia et al. (16) reported that the disease starts before the age of 10 in $60 \%$ of patients. In their study, Mimouni et al. (17) reported the onset age of the dis- 
Table 2. Distribution of Homozygous, Heterozygous Genes and Allele Frequency

\begin{tabular}{|c|c|c|c|c|c|c|}
\hline \multirow[t]{2}{*}{ Mutation } & \multicolumn{2}{|c|}{ Heterozygous } & \multicolumn{2}{|c|}{ Homozygous } & \multirow[t]{2}{*}{ Number of Alleles } & \multirow[t]{2}{*}{ Allele Frequency } \\
\hline & No. & $\%$ & No. & $\%$ & & \\
\hline M694V & 24 & 29.3 & 3 & 37.5 & 30 & 21.9 \\
\hline $\operatorname{M680I}(G / C)$ & 4 & 4.9 & 0 & 0 & 4 & 2.9 \\
\hline V726A & 7 & 8.5 & 0 & 0 & 7 & 5.1 \\
\hline R202Q & 39 & 47.6 & 6 & 75.0 & 51 & 37.2 \\
\hline E148Q & 30 & 36.6 & 1 & 12.5 & 32 & 23.4 \\
\hline M694I & 1 & 1.2 & 0 & 0 & 1 & 0.7 \\
\hline A744S & 2 & 2.4 & 0 & 0 & 2 & 1.5 \\
\hline R761H & 3 & 3.7 & 0 & 0 & 3 & 2.2 \\
\hline F479L & 2 & 2.4 & 0 & 0 & 2 & 1.5 \\
\hline E167D & 1 & 1.2 & 0 & 0 & 1 & 0.7 \\
\hline R408Q & 2 & 2.4 & 0 & 0 & 2 & 1.5 \\
\hline G304R & 2 & 2.4 & 0 & 0 & 2 & 1.5 \\
\hline
\end{tabular}

Table 3. Descriptive Properties According to Genetic Mutation

\begin{tabular}{|c|c|c|c|}
\hline Varibales & $\begin{array}{l}\text { Mutation (-) } \\
\text { mean } \pm \text { SD }\end{array}$ & $\begin{array}{l}\text { Mutation }(+) \\
\text { mean } \pm S D\end{array}$ & P Value \\
\hline Age, $y$ & $9.48 \pm 4.57$ & $9.29 \pm 4.35$ & 0.793 \\
\hline \multirow[t]{2}{*}{ Begining of the symptoms, $y$} & $9.10 \pm 4.36$ & $8.56 \pm 4.10$ & 0.439 \\
\hline & No. (\%) & No. $(\%)$ & \\
\hline Gender & & & 0.205 \\
\hline Female & $35(44.9)$ & $43(55.1)$ & \\
\hline Male & $25(34.7)$ & $47(65.3)$ & \\
\hline Homeland & & & 0.588 \\
\hline East Anatolian & $35(44.3)$ & $44(55.7)$ & \\
\hline Middle Anatolia & $3(23.1)$ & $10(76.9)$ & \\
\hline North Anatolian & $19(39.6)$ & $29(60.4)$ & \\
\hline South Anatolian & $2(40.0)$ & $3(60.0)$ & \\
\hline West Anatolian & $1(20.0)$ & $4(80.0)$ & \\
\hline Consanguinity & & & 0.049 \\
\hline$(-)$ & $51(44.3)$ & $64(55.7)$ & \\
\hline$(+)$ & $9(25.7)$ & $26(74.3)$ & \\
\hline Complaint to the mother & & & 0.006 \\
\hline$(-)$ & $60(100.0)$ & $80(88.9)$ & \\
\hline$(+)$ & $0(0.0)$ & $10(11.1)$ & \\
\hline Complaint to the father & & & 0.022 \\
\hline$(-)$ & $60(100.0)$ & $82(91.1)$ & \\
\hline$(+)$ & $0(0.0)$ & $8(8.9)$ & \\
\hline Complaint to siblings & & & 0.359 \\
\hline$(-)$ & $56(93.3)$ & $80(88.9)$ & \\
\hline$(+)$ & $4(6.7)$ & $10(11.1)$ & \\
\hline
\end{tabular}

ease in Turks to be 12.3 years. In our study, the onset age of FMF was determined to be averagely 8.77 years.
The Turkish FMF study group reported that FMF is 1.2 times more in male patients than female patients (10). Majeed et al.'s study (15) comprised 54\% female and 46\% male patients. In our study, $52 \%$ of the patients are female and $48 \%$ male, which is consistent with the studies reported. In the study featuring the Turkish FMF study group, 18.9\% of the parents had consanguineous marriage (10). The ratio of consanguineous marriage in our study was $23.3 \%$.

There are no precise diagnostic physical examinations or laboratory findings in FMF. Fever and abdominal pain are the most prevalent symptoms $(10,18)$. The complaints by frequency order in the Turkish FMF study group were reported to be abdominal pain (93\%), fever (91.3\%), arthritis (58.3\%), and chest pain (4\%) (10). In another study, it was reported that abdominal pain and fever were on the top of the presenting complaints (19). Fever (100\%), abdominal pain (82\%), chest pain (43\%), and arthritis (37\%) were detected in most Arabs (20). The most frequent symptoms in those of Jewish origin were fever (100\%), abdominal pain (95\%), and arthritis (77\%)(21). The most frequent symptoms in Armenians were fever (100\%), abdominal pain (96\%), chest pain (87\%), and arthritis (37\%) (22). In our study, the most frequent reasons were abdominal pain (44.7\%), arthralgia (20\%), fever (16.7\%), chest pain (1.3\%), and other reasons (20\%). In compliance with the previous studies, it was observed in our study that abdominal pain is the most frequent complaint.

While the etiology of FMF is not fully known, the ethnic origin, genetic predisposition, and environmental factors may be responsible for pathogenesis (23). Currently, there are 317 mutations in the MEFV gene(6). Five mutations have 
Table 4. Distribution of Genotype Frequencies

\begin{tabular}{|c|c|c|}
\hline Varibales & Genotype $(n=150)$ & Frequencies (\%) \\
\hline \multicolumn{3}{|l|}{ Heterozygous $(\mathbf{n}=55$ ) } \\
\hline A744S & 1 & 0.7 \\
\hline E148Q & 16 & 10.7 \\
\hline E148V & 1 & 0.7 \\
\hline G304R & 1 & 0.7 \\
\hline M680I & 1 & 0.7 \\
\hline M694V & 9 & 6.0 \\
\hline R202Q & 22 & 14.7 \\
\hline $\mathrm{R} 761 \mathrm{H}$ & 2 & 1.3 \\
\hline V726A & 2 & 1.3 \\
\hline \multicolumn{3}{|l|}{ Homozygous $(n=8)$} \\
\hline E148Q homo & 1 & 0.7 \\
\hline M694V homo & 1 & 0.7 \\
\hline M694V homo, R202Q homo & 2 & 1.3 \\
\hline R202Q homo & 4 & 2.7 \\
\hline \multicolumn{3}{|l|}{ Compaund heterozygous ( $n=19$ ) } \\
\hline Comp. E148Q, M680I & 1 & 0.7 \\
\hline Comp. E148Q, M694V & 1 & 0.7 \\
\hline comp. E148Q, F479L & 1 & 0.7 \\
\hline comp. M694V, R761H & 1 & 0.7 \\
\hline E148Q, R202Q & 4 & 2.7 \\
\hline F479L, E167D & 1 & 0.7 \\
\hline M680I, V726A & 1 & 0.7 \\
\hline M694V, E148Q & 1 & 0.7 \\
\hline M694V, R202Q & 6 & 4.0 \\
\hline R202Q, E148Q & 1 & 0.7 \\
\hline V726A, A744S & 1 & 0.7 \\
\hline \multicolumn{3}{|l|}{ Complex heterozygous $(\mathbf{n}=\mathbf{8})$} \\
\hline $\mathrm{E} 148 \mathrm{Q}, \mathrm{M} 694 \mathrm{~V}, \mathrm{M} 694 \mathrm{I}$ & 1 & 0.7 \\
\hline E148Q, V726A, P369S, R408Q & 1 & 0.7 \\
\hline G304R, R202Q, M694V & 1 & 0.7 \\
\hline M694V, R202Q, E148Q & 1 & 0.7 \\
\hline $\mathrm{M} 694 \mathrm{~V}, \mathrm{R} 202 \mathrm{Q}, \mathrm{M} 680 \mathrm{I}(\mathrm{g}>\mathrm{c})$ & 1 & 0.7 \\
\hline M694V, R202Q, V726A & 1 & 0.7 \\
\hline $\mathrm{M} 694 \mathrm{~V}, \mathrm{~V} 726 \mathrm{~A}, \mathrm{R} 202 \mathrm{Q}$ & 1 & 0.7 \\
\hline P369S, R408Q, R202Q, E148Q & 1 & 07 \\
\hline
\end{tabular}

been defined as the most frequent reason for the disease; these are four mutations in the 10th exon (M680I, M694V, M694I, V726A) and one (E148Q) mutation in the 2nd exon (5). It is believed that homozygous M694V mutation causes a severe clinical course and the development of amyloido$\operatorname{sis}(24)$.

R202Q was first defined by Bernot in 1998, and it is believed that it can be a prevalent polymorphism. It has been reported that to emerge the disease symptoms, the $\mathrm{R} 202 \mathrm{Q}$ gene change should be accompanied by a mutation related to the disease, and this change is significant for a diagnosis (25). While R202Q (37.2\%) was observed to be the mutation with the highest frequency, this was followed by E148Q
(23.4\%), M694V (21.9\%), V726A (5.1\%), M680I (2.9\%), R761H (2.2\%), A744S, F479L, R408Q, G304R(1.5\%), M694I, and E167D (0.7\%). In the study carried out in Turkey by the FMF study group in 2005, M694V (51.4\%), M680I (14.4\%), V726A (8.6\%) were found to be most prevalent in the patients whose gene mutation analysis was performed $(10,26)$. In our study, R202Q mutation was identified as the most common mutation. In the study by Caglayan et al. (27), M694V (32\%) was the most frequent mutation on the basis of alleles, followed by E148Q (20.6\%), V726A (17\%), M680I(G/C) (14.5\%), and P369S (10.8\%) mutations. In our study, while the E148Q mutation was the second most frequent at a rate of $23.4 \%$, M680I (G/A) and I692del mutations were not determined.

In the study by Demirkaya et al. (28) consisting of 330 patients, M694V was observed at a rate of $50 \%$, M680I at a rate of $14.1 \%$, V726A at a rate of $9.70 \%$, and the E148Q point mutation was observed at a rate of $1.37 \%$; the prevalence ranking of the mutations was different from our study. In another study performed by Dundar et al. (29), the allele frequency was reported to be M694V 14.68\%, M680I (G/C) 7.62\%, E148Q 5.15\%, and V726A 4.76\%. In a study carried out on 153 FMF patients in Syria, the most prevalent mutations were in order of frequency, M694V (36.5\%), V726A (15.2\%), E148Q (14.5\%), M680I (G/C) (13.2\%), and M694I (10.2\%) (30). In our study, the V726A mutation was in fourth place, and one M694I mutation was determined.

In their study consisting of 2067 patients around Kayseri (30) found that M694V was $50.50 \%$, M680I was $21.26 \%$, E148Q was $19.86 \%$, V726A was $15.34 \%$, and $\mathrm{R} 761 \mathrm{H}$ was $4.4 \%$. The M680I mutation was found to be in fifth place in our study. In their study carried out on 524 patients in Iran, Bonyadi et al. (31) found that the most prevalent mutation was M694V at a rate of $42.4 \%$, followed by V726A at a rate of $17 \%$, E148Q at a rate of $16.2 \%$, M680I at a rate of $15.2 \%$, and $\mathrm{R} 761 \mathrm{H}$ at a rate of $4.7 \%$. All patients in the group of this study carried out in Iran consist of Azeri Turks. In our study, E148Q mutation came before the M694V mutation in the frequency ranking. V726A mutation ranked in fourth place.

In our study, the R202Q mutation was determined to be the most frequen, different from other studies. The complaints that accompany R202Q, E148Q, and M694V mutations most frequently were abdominal pain, arthralgia and high fever, which is consistent with the literature $(32,33)$.

Finally, it was determined that the most frequently observed mutation in our study was R202Q, followed by E148Q. Our region receives intense migration from all Anatolian regions. For this reason, we think that the results of our work are important in terms of collectively reflecting the data of our country. 
Table 5. Genotype Distribution by Complaints

\begin{tabular}{|c|c|c|c|c|c|c|c|}
\hline \multirow[t]{2}{*}{ Varibles } & \multirow[t]{2}{*}{ No. } & \multicolumn{2}{|c|}{ Abdominal pain } & \multicolumn{2}{|c|}{ Arthralgia } & \multicolumn{2}{|c|}{ Fever } \\
\hline & & No. & $\%$ & No. & $\%$ & No. & $\%$ \\
\hline M694V & 27 & 13 & 48.1 & 5 & 18.5 & 5 & 18.5 \\
\hline M680I & 4 & 0 & 0 & 1 & 25 & 0 & 0 \\
\hline V726A & 7 & 4 & 57.1 & 0 & 0 & 1 & 14.3 \\
\hline R202Q & 45 & 20 & 44.4 & 10 & 22.2 & 6 & 13.3 \\
\hline E148Q & 31 & 13 & 41.9 & 8 & 25.8 & 6 & 19.4 \\
\hline M694I & 1 & 0 & 0 & 0 & 0 & 1 & 100 \\
\hline A744S & 2 & 2 & 100 & 0 & 0 & 0 & 0 \\
\hline R761H & 3 & 1 & 33.3 & 0 & 0 & 1 & 33.3 \\
\hline F479L & 2 & 1 & 50 & 0 & 0 & 1 & 50 \\
\hline E167D & 1 & 0 & 0 & 0 & 0 & 1 & 100 \\
\hline R408Q & 2 & 0 & 0 & 1 & 50 & 1 & 50 \\
\hline G304R & 2 & 1 & 50 & 1 & 50 & 0 & 0 \\
\hline
\end{tabular}

\section{Footnote}

Ethics Committee Approval: Approval was taken from Hospital ethics committee and informed written consent was obtained from the patients in accordance with the Declaration of Helsinki.

\section{References}

1. Samuels J, Aksentijevich I, Torosyan Y, Centola M, Deng Z, Sood R, et al. Familial Mediterranean fever at the millennium. Clinical spectrum, ancient mutations, and a survey of 100 American referrals to the National Institutes of Health. Medicine (Baltimore). 1998;77(4):268-97. doi: 10.1097/00005792-199807000-00005. [PubMed: 9715731].

2. Ozcakar ZB, Yalcinkaya F, Yuksel S, Acar B, Gokmen D, Ekim M. Possible effect of subclinical inflammation on daily life in familial Mediterranean fever. Clin Rheumatol. 2006;25(2):149-52. doi: 10.1007/s10067005-1148-z. [PubMed: 16172947].

3. Berkun Y, Eisenstein EM. Diagnostic criteria of familial Mediterranean fever. Autoimmun Rev. 2014;13(4-5):388-90. doi: 10.1016/j.autrev.2014.01.045. [PubMed: 24424166].

4. Booth DR, Lachmann HJ, Gillmore JD, Booth SE, Hawkins PN. Prevalence and significance of the familial Mediterranean fever gene mutation encoding pyrin Q148. QJM. 2001;94(10):527-31. doi: 10.1093/qjmed/94.10.527. [PubMed: 11588211].

5. Yepiskoposyan L, Harutyunyan A. Population genetics of familial Mediterranean fever: a review. Eur J Hum Genet. 2007;15(9):911-6. doi: 10.1038/sj.ejhg.5201869. [PubMed: 17568393].

6. infevers: an online database for autoinflammatory mutations [cited 6 Apr]. Available from: http://fmf.igh.cnrs.fr/ISSAID/infevers/.

7. Yilmaz G, Senes M, Kayalp D, Yucel D. Is Turkish MEFV Mutations Spectrum Different Among Regions?.J Clin Lab Anal. 2016;30(5):641-4. doi: 10.1002/jcla.21915. [PubMed: 26892483].

8. Stojanov S, Kastner DL. Familial autoinflammatory diseases: genetics, pathogenesis and treatment. Curr Opin Rheumatol. 2005;17(5):586-99. doi: 10.1097/bor.0000174210.78449.6b. [PubMed: 16093838].

9. Ancient missense mutations in a new member of the RoRet gene family are likely to cause familial Mediterranean fever. The Interna- tional FMF Consortium. Cell. 1997;90(4):797-807. doi: 10.1016/S00928674(00)80539-5. [PubMed: 9288758].

10. French F. A candidate gene for familial Mediterranean fever. Nat Genet. 1997;17(1):25-31. doi: 10.1038/ng0997-25. [PubMed: 9288094].

11. Livneh A, Langevitz P, Zemer D, Zaks N, Kees S, Lidar T, et al. Criteria for the diagnosis of familial mediterranean fever. Arth Rhem. 1997;40(10):1879-85. doi: 10.1002/art.1780401023.

12. Bakkaloglu A. Familial Mediterranean fever. Pediatr Nephrol. 2003;18(9):853-9. doi: 10.1007/s00467-003-1185-2. [PubMed: 12836090].

13. Tunca M, Akar S, Onen F, Ozdogan H, Kasapcopur O, Yalcinkaya F, et al. Familial Mediterranean fever (FMF) in Turkey: results of a nationwide multicenter study. Medicine (Baltimore). 2005;84(1):1-11. doi: 10.1097/01.md.0000152370.84628.0c. [PubMed: 15643295].

14. Ben-Chetrit E, Levy M. Familial Mediterranean fever. Lancet. 1998;351(9103):659-64. doi: 10.1016/S0140-6736(97)09408-7. [PubMed: 9500348].

15. Majeed HA, Rawashdeh M, el-Shanti H, Qubain H, Khuri-Bulos N, Shahin HM. Familial Mediterranean fever in children: the expanded clinical profile. QJM. 1999;92(6):309-18. doi: 10.1093/oxfordjournals.qjmed.a030153. [PubMed: 10616706].

16. Gedalia A,Adar A, Gorodischer R. Familial Mediterranean fever in children.J Rheumatol Suppl. 1992;35:1-9. [PubMed: 1433029].

17. Mimouni A, Magal N, Stoffman N, Shohat T, Minasian A, Krasnov M, et al. Familial Mediterranean fever: effects of genotype and ethnicity on inflammatory attacks and amyloidosis. Pediatrics. 2000;105(5):E70. doi: 10.1542/peds.105.5.e70. [PubMed: 10799634].

18. Yilmaz E, Ozen S, Balci B, Duzova A, Topaloglu R, Besbas N, et al. Mutation frequency of Familial Mediterranean Fever and evidence for a high carrier rate in the Turkish population. Eur J Hum Genet. 2001;9(7):553-5. doi: 10.1038/sj.ejhg.5200674. [PubMed: 11464248].

19. Ozen S, Demirkaya E, Amaryan G, Kone-Paut I, Polat A, Woo P, et al. Results from a multicentre international registry of familial Mediterranean fever: impact of environment on the expression of a monogenic disease in children. Ann Rheum Dis. 2014;73(4):662-7. doi: 10.1136/annrheumdis-2012-202708. [PubMed: 23463692].

20. Rawashdeh MO, Majeed HA. Familial Mediterranean fever in Arab children: the high prevalence and gene frequency. Eur J Pediatr. 1996;155(7):540-4. doi: 10.1007/BF01957901. [PubMed: 8831074]. 
21. Sohar E, Gafni J, Pras M, Heller H. Familial Mediterranean fever. A survey of 470 cases and review of the literature. Am J Med. 1967;43(2):22753. doi: 10.1016/0002-9343(67)90167-2. [PubMed: 5340644].

22. Schwabe AD, Peters RS. Familial Mediterranean Fever in Armenians Analysis of 100 cases. Medicine (Baltimore). 1974;53(6):453-62. doi: 10.1097/00005792-197411000-00005. [PubMed: 4437392].

23. Ben-Chetrit E, Touitou I. The impact of MEFV gene identification on FMF: an appraisal after 15 years. Clin Exp Rheumatol. 2012;30(3 Suppl 72):S3-6. [PubMed: 22935552].

24. Kasapcopur O, Arısoy N. . Familial Mediterranean fever and other autoinflammatory diseases. Turk Arch Pediatr. 2006;41:9-17.

25. Bernot A, da Silva C, Petit JL, Cruaud C, Caloustian C, Castet V, et al. Non-founder mutations in the MEFV gene establish this gene as the cause of familial Mediterranean fever (FMF). Hum Mol Genet. 1998;7(8):1317-25. doi:10.1093/hmg/7.8.1317. [PubMed: 9668175].

26. Giancane G, Ter Haar NM, Wulffraat N, Vastert SJ, Barron K, Hentgen $\mathrm{V}$, et al. Evidence-based recommendations for genetic diagnosis of familial Mediterranean fever. Ann Rheum Dis. 2015;74(4):635-41. doi: 10.1136/annrheumdis-2014-206844. [PubMed: 25628446].

27. Caglayan AO, Demiryilmaz F, Ozyazgan I, Gumus H. MEFV gene compound heterozygous mutations in familial Mediterranean fever phenotype: a retrospective clinical and molecular study. Nephrol Dial Transplant. 2010;25(8):2520-3. doi: 10.1093/ndt/gfp632. [PubMed: 19934083].

28. Demirkaya E, Tunca Y, Gok F, Ozen S, Gul D. A very frequent mu- tation and remarkable association of $\mathrm{R} 761 \mathrm{H}$ with $\mathrm{M} 694 \mathrm{~V}$ mutations in Turkish familial Mediterranean fever patients. Clin Rheumatol. 2008;27(6):729-32. doi: 10.1007/s10067-007-0780-1. [PubMed: 18000697].

29. Dundar M, Emirogullari EF, Kiraz A, Taheri S, Baskol M. Common Familial Mediterranean Fever gene mutations in a Turkish cohort. Mol Biol Rep. 2011;38(8):5065-9. doi: 10.1007/s11033-010-0652-7. [PubMed: 21153919].

30. Jarjour RA. Familial Mediterranean fever in Syrian patients: MEFV gene mutations and genotype-phenotype correlation. Mol Biol Rep. 2010;37(1):1-5. doi: 10.1007/s11033-009-9475-9. [PubMed: 19253030].

31. Bonyadi M, Esmaeili M, Jalali H, Somi MH, Ghaffari A, Rafeey M, et al. MEFV mutations in Iranian Azeri Turkish patients with familial Mediterranean fever. Clin Genet. 2009;76(5):477-80. doi: 10.1111/j.13990004.2009.01270.x. [PubMed:19863562].

32. Kilinc M, Ganiyusufoglu E, Sager H, Celik A, Olgar S, Cetin GY, et al The report of sequence analysis on familial Mediterranean fever gene (MEFV) in South-eastern Mediterranean region (Kahramanmaras) of Turkey. Rheumatol Int. 2016;36(1):25-31. doi:10.1007/s00296-015-3329-7. [PubMed: 26215181].

33. Kilic A, Varkal MA, Durmus MS, Yildiz I, Yildirim ZN, Turunc G, et al Relationship between clinical findings and genetic mutations in patients with familial Mediterranean fever. Pediatr Rheumatol Online J. 2015;13:59. doi: 10.1186/s12969-015-0057-1. [PubMed: 26759267]. 